\title{
Have Nitrate Concentrations Changed in Water in the Alluvial Aquifer of the Upper Black Squirrel Creek Basin Since 1984?
}

\author{
-By Daniel Brendle
}

U.S. Department of the Interior-U.S. Geological Survey

\section{Introduction}

$\mathcal{L}_{\text {he alluvial aquifer of the upper Black Squirrel Creek }}$ Basin, about 25 miles east of Colorado Springs, supplies most of the water for irrigation and domestic use in the basin and, since 1964, supplies water for export to the Colorado Springs area (fig. 1). The alluvial aquifer underlies about 90 square miles of the upper Black Squirrel Creek Basin and is underlain by the Denver Basin bedrock aquifers: the Dawson, Denver, Arapahoe, and Laramie-Fox Hills aquifers (Watts, 1995). Most wells in the basin tap the alluvial aquifer and have high yields, ranging from about 10 gallons per minute ( $\mathrm{gal} / \mathrm{min}$ ) for stock wells to more than $1,000 \mathrm{gal} / \mathrm{min}$ for high-capacity irrigation wells. Because of increasing demand for ground water in the basin, the U.S. Geological Survey, in cooperation with the Cherokee Metropolitan District (CMD), collected samples from 36 wells in the upper Black Squirrel Creek alluvial aquifer in August 1984 to determine the distribution of concentrations of nitrite plus nitrate as nitrogen (referred to as nitrate). Twenty-eight of the 36 wells sampled in August 1984 were resampled in August 1996 to determine whether nitrate concentrations in the alluvial aquifer changed since 1984. This fact sheet discusses changes in nitrate concentrations in the upper Black Squirrel Creek alluvial aquifer between 1984 and 1996, where those changes occurred, and possible causes for the changes in nitrate concentrations.

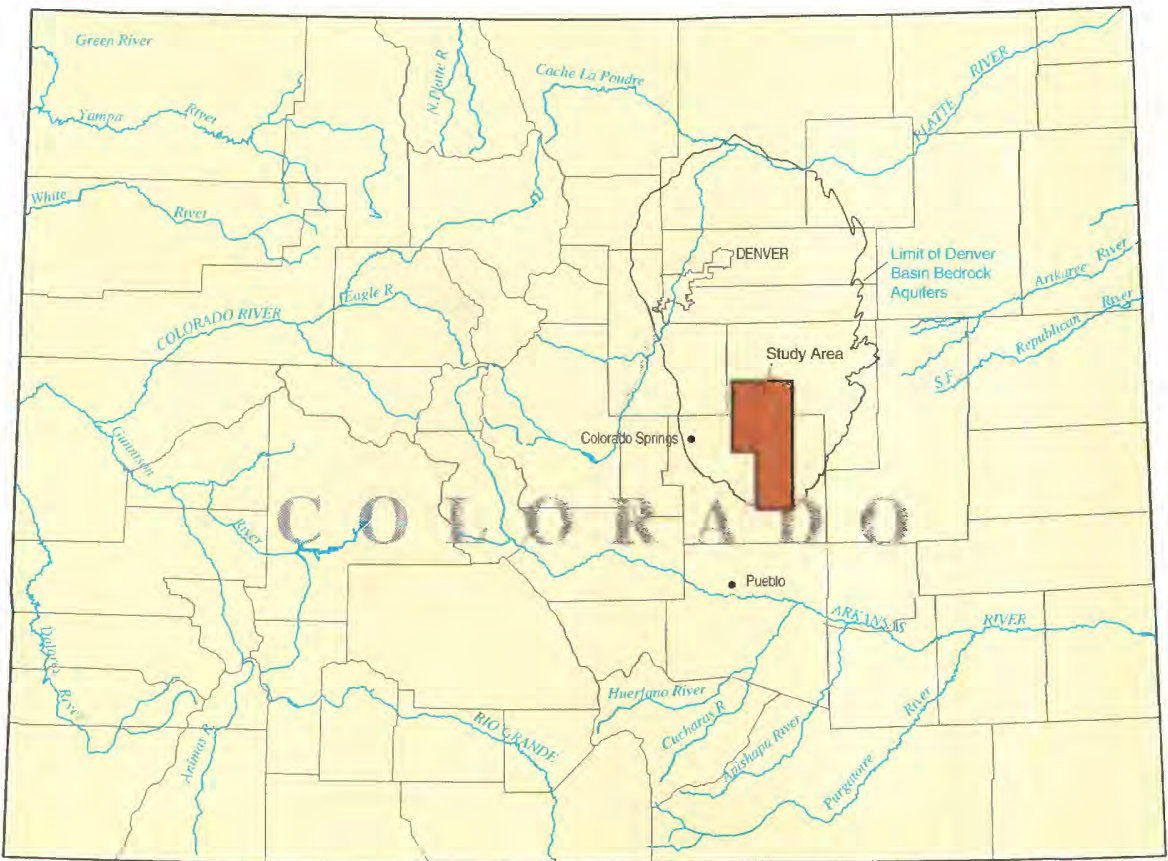

Base modified from U.S. Geological Survey, digital data, 1:2,000,000, 1972

\section{Why is high nitrate in drinking water a problem?}

Consumption of water containing a concentration of nitrate greater than 10 milligrams per liter $(\mathrm{mg} / \mathrm{L})$ (one milligram per liter is about equal to one part per million parts) potentially can have long-term, detrimental health effects, primarily in infants. Thus, the U.S. Environmental Protection Agency established the maximum contaminant level (MCL) for nitrate in drinking water as $10 \mathrm{mg} / \mathrm{L}$. Nitrate that is ingested can be converted to nitrite in the human digestive system by bacteria present in the mouth and digestive system (Terblanche, 1991). Nitrite can convert hemoglobin in the blood to methemoglobin, which is not capable of transporting oxygen to tissues. Children younger than 1 year are most susceptible to methemoglobinemia, or blue-baby syndrome. because they have a higher concentration of methemoglobin in their blood than older children or adults. If left untreated, methemoglobinemia can result in death due to a deprivation of oxygen to vital tissues. There also is some evidence that nitrite consumed in or derived from foods or water can indirectly cause the formation of some cancers (Terblanche, 1991).

\section{Where does nitrate come from?}

Nitrate occurs naturally, but generally, water that is unaffected by human practices has relatively small concentrations of nitrate. Human practices, however, can cause nitrate to become concentrated in the environment. Some common sources of nitrate in ground water in the upper Black Squirrel Creek alluvial aquifer include: animal manure applied to croplands as fertilizer. commercial fertilizers, manure in feedlots and dairies, and sewage and septic leachfield effluent. Nitrate from these sources can leach from the land surface to ground water when irrigation water applied to the land surface or runoff from precipitation percolates and recharges the alluvial aquifer.

\section{Nitrate concentrations in 1984 and 1996}

Samples from 5 of the 36 wells sampled in 1984 (table 1) had nitrate concentrations greater than the MCL of $10 \mathrm{mg} / \mathrm{L}$. Nitrate concentrations in wells sampled in August 1984 (table 1) are shown in figure 2.

Analysis of samples collected annually in August from 1984 to 1996 in the CMD Iwell (well 22 in table 1) indicates that nitrate

Figure 1. Location of the study area.

- 25 KILOMETERS 
Table 1. Nitrate concentrations for wells sampled in 1984 and 1996

[+, increase; -, decrease; --, no data]

\begin{tabular}{|c|c|c|c|c|}
\hline \multirow{2}{*}{$\begin{array}{c}\text { Well } \\
\text { number }\end{array}$} & \multirow{2}{*}{$\begin{array}{c}\text { Local } \\
\text { identification } \\
\text { number }\end{array}$} & \multicolumn{2}{|c|}{ Concentrations } & \multirow{2}{*}{$\begin{array}{c}\text { Difference } \\
\text { between } \\
1984 \text { and } \\
1996\end{array}$} \\
\hline & & 1984 & 1996 & \\
\hline 1 & SC01506326BAB & 5.5 & 5.8 & +0.3 \\
\hline 2 & SC01506325BBA & 4.6 & 5.6 & +1.0 \\
\hline 3 & SC01506332DAB & 4.3 & - & -- \\
\hline 4 & SC01506218ACB & 1.2 & .16 & -1.0 \\
\hline 5 & SC01506312DCC & 3.5 & 4.1 & +.6 \\
\hline 6 & SC01506310DCC & 5.5 & 5.6 & +.1 \\
\hline 7 & SC01506301AAA & 5.1 & 7.9 & +2.8 \\
\hline 8 & SC01406336AAB & 4.4 & 5.8 & +1.4 \\
\hline 9 & SC01406232BBA & 4.1 & 4.5 & +.4 \\
\hline 10 & SC01406231BAA & 5.1 & - & - \\
\hline 11 & SC01406220DBC & 8.4 & -- & -- \\
\hline 12 & SC01406216CCC & 8.1 & - & -- \\
\hline 13 & SC01406313DDA & 4.4 & 5.3 & +.9 \\
\hline 14 & SC01406312DCD & 4.2 & 4.4 & +.2 \\
\hline 15 & SC01406208CCB & 4.8 & 7.4 & +2.6 \\
\hline 16 & SC01406205CAA & 7.0 & 7.1 & +.1 \\
\hline 17 & SC01406303DCC & .69 & 5.0 & +4.3 \\
\hline 18 & SC01406205ACD & 6.0 & - & -- \\
\hline 19 & SC01406205BBB & 6.5 & 5.7 & -.8 \\
\hline 20 & SC01306231ACC & 6.0 & 8.4 & +2.4 \\
\hline 21 & SC01306334ABB & 11 & 11 & 0 \\
\hline 22 & SC01306230ACC1 & 6.0 & 8.6 & +2.6 \\
\hline 23 & SC01306219CDB & 6.5 & 6.3 & -.2 \\
\hline 24 & SC01306221BDD & .16 & -- & - \\
\hline 25 & SC01306322ADB & 2.9 & 2.5 & -.4 \\
\hline 26 & SC01306314ABB & 1.7 & .25 & -1.4 \\
\hline 27 & SC01306221AAB & 3.6 & -- & - \\
\hline 28 & SC01306312CDB & 2.8 & 3.1 & +.3 \\
\hline 29 & SC01306209BBB & 33 & 25 & -8 \\
\hline 30 & SC01306301CCC & 6.5 & 7.8 & +1.3 \\
\hline 31 & SC01306306DAA & .07 & .05 & -.02 \\
\hline 32 & SC01206336ACC & 6.3 & 6.8 & +.5 \\
\hline 33 & SC01206230CDC & 11 & .69 & -10 \\
\hline 34 & SC01206230BDB & 11 & 8.4 & -2.6 \\
\hline 35 & SC01 206322BBB & 1.7 & 2.8 & +1.1 \\
\hline 36 & SC01206314DDC & 72 & - & -- \\
\hline
\end{tabular}

concentrations increased from 6.0 to $8.6 \mathrm{mg} / \mathrm{L}$ between 1984 and 1996, an average increase of about $0.22 \mathrm{mg} / \mathrm{L}$ per year (fig. 3).

The 1996 study was done to assess whether the increase in nitrate concentration in well 22 was localized or was indicative of increases in nitrate concentrations throughout a greater area of the alluvial aquifer.

Eight of the 36 wells sampled in 1984 were not resampled in 1996 because they were redrilled and deepened to tap the underlying bedrock aquifers, the well owners denied permission to sample their wells, or the wells were inactive. Samples were collected during August of both years because nitrate concentrations in the upper Black Squirrel Creek alluvial aquifer vary seasonally, and sampling during the same month minimizes these



Figure 2. Concentrations of nitrite plus nitrate as nitrogen (nitrate) in the alluvial aquifer of upper Black Squirrel Creek, August 1984

seasonal variations. Some of the differences in nitrate concentrations measured between 1984 and 1996 (table 1) could have resulted from sampling and analytical uncertainty or short-term variations in climatic and hydrologic conditions. Analysis of duplicate samples, obtained from the same well at the same time, indicated that the sampling and analytical uncertainty in reported nitrate concentrations was less than $0.1 \mathrm{mg} / \mathrm{L}$. However, an analysis of variations in nitrate concentrations measured in samples collected annually in August from well 22 from 1984 to 1996 indicated that deviations from a trend as large as about $0.5 \mathrm{mg} / \mathrm{L}$ occurred periodically (fig. 3). The trend line was calculated using the Mann-Kendall trend test on nitrate concentrations from samples obtained from well 22 in August of each year from 1984 to 1996.

Nitrate concentrations measured in the samples collected from 28 wells during August 1996 are listed in table 1 and are shown in figure 4 . Nitrate concentrations were less than $1.0 \mathrm{mg} / \mathrm{L}$ in 4 wells; between 1.0 and $5.0 \mathrm{mg} / \mathrm{L}$ in 7 wells; between 5.1 and $10 \mathrm{mg} / \mathrm{L}$ (the MCL) in 15 wells; $11 \mathrm{mg} / \mathrm{L}$ in well 21; and $25 \mathrm{mg} / \mathrm{L}$ in well 29 (fig. 4; table 1). North of Highway 94 , most wells with nitrate concentrations in the range of 5.1 to 


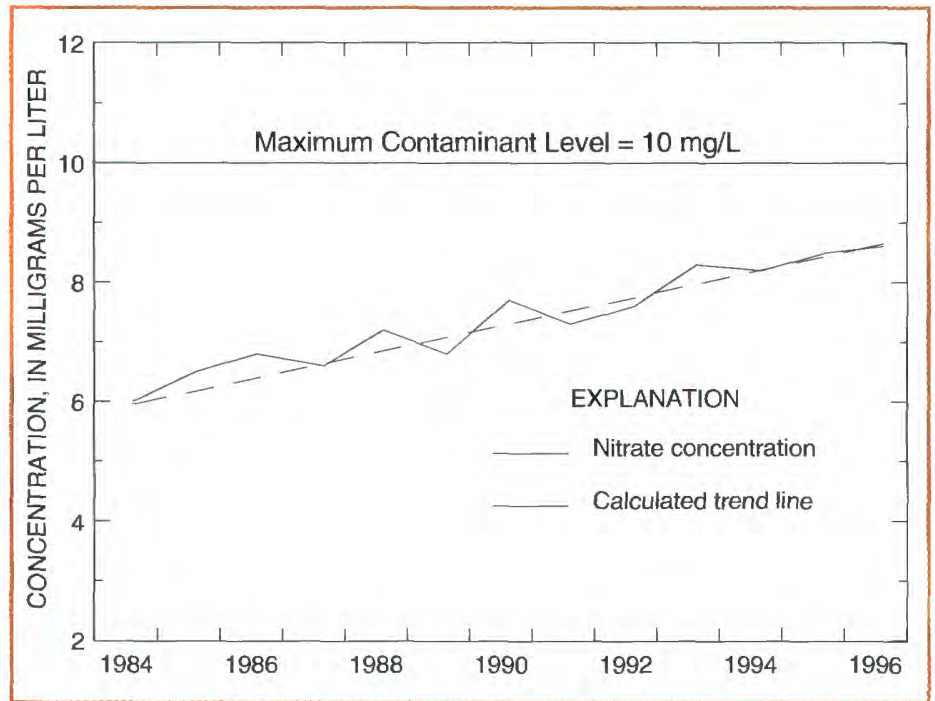

Figure 3. Concentrations of nitrite plus nitrate as nitrogen (nitrate), in Cherokee Metropolitan District 1-well (well 22 in table 1) for samples collected annually in August from 1984 to 1996.

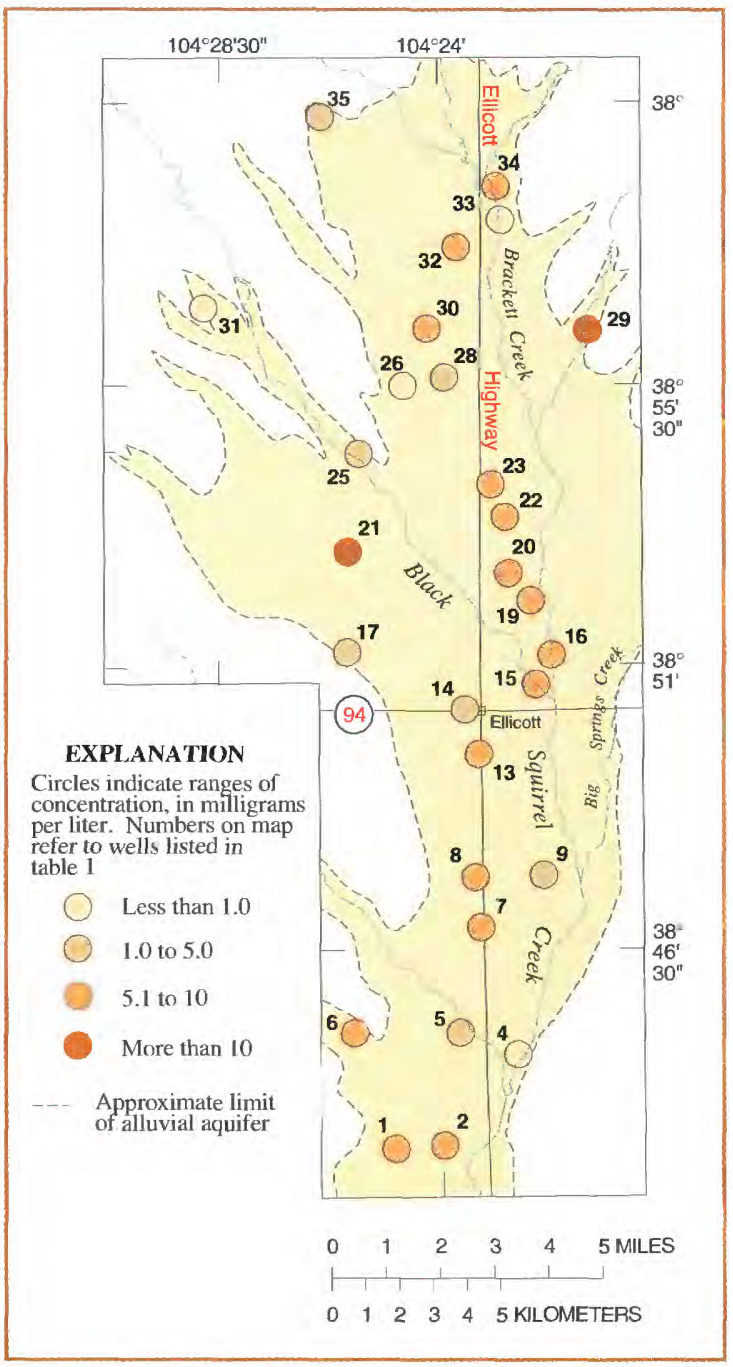

Figure 4. Concentrations of nitrite plus nitrate as nitrogen (nitrate) in the alluvial aquifer of upper Black Squirrel Creek, August 1996.

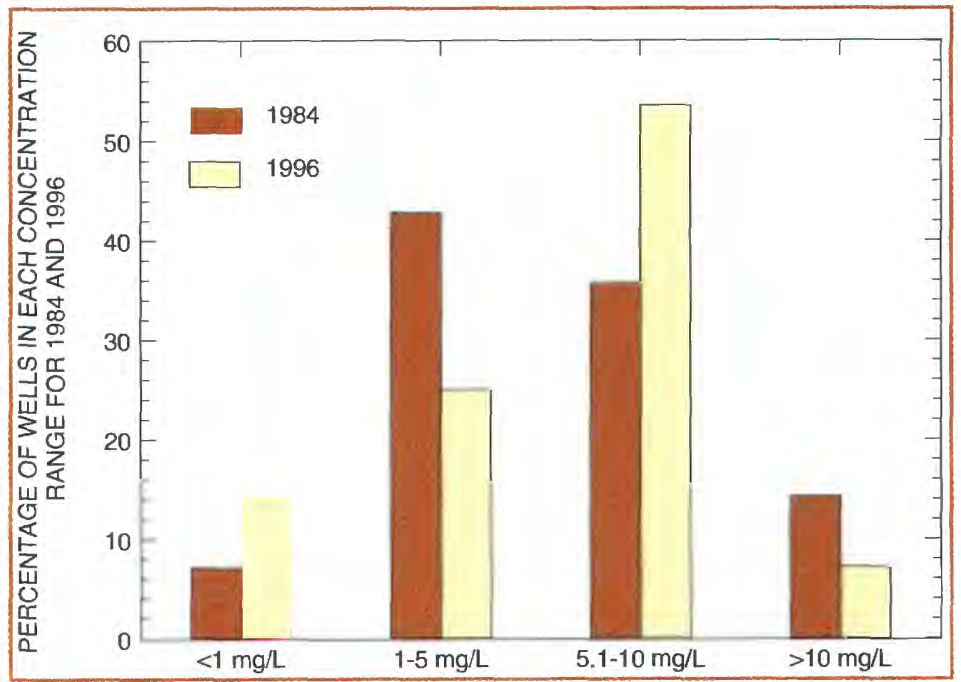

Figure 5. Percentage of wells in each nitrate concentration range for the 28 wells sampled in both 1984 and 1996.

$10 \mathrm{mg} / \mathrm{L}$ were in the central region of the aquifer, whereas south of Highway 94, most wells in that concentration range were in the western region of the aquifer.

\section{Have nitrate concentrations changed in the alluvial aquifer between 1984 and 1996 ?}

For the wells sampled both years, the proportion of samples with nitrate concentrations in the 5.1 to $10 \mathrm{mg} / \mathrm{L}$ range increased from about 36 to about 54 percent between 1984 and 1996 (fig 5). The proportion of samples with nitrate concentrations in the 1.0 to $5.0 \mathrm{mg} / \mathrm{L}$ range decreased from about 43 to 25 percent between 1984 and 1996. Samples collected in 1984 from wells 33 and 34 contained nitrate concentrations of $11 \mathrm{mg} / \mathrm{L}$, which decreased to less than $10 \mathrm{mg} / \mathrm{L}$ in the samples collected in 1996 . Well 21 had a nitrate concentration of $11 \mathrm{mg} / \mathrm{L}$ in both years, and the nitrate concentration in well 29 decreased from $33 \mathrm{mg} / \mathrm{L}$ in 1984 to $25 \mathrm{mg} / \mathrm{L}$ in 1996.

Nitrate concentrations from the 28 wells sampled in both years (table 1) were used to generate a map showing the distribution of differences in nitrate concentrations between 1984 and 1996 and the magnitude and direction (increase, decrease, or no change) of those differences (fig. 6). Samples from 16 wells (about 57 percent) in the alluvial aquifer indicated small to no difference in nitrate concentrations (difference of $\pm 1 \mathrm{mg} / \mathrm{L}$ or less). Samples from 8 wells (about 29 percent) indicated moderate increases in nitrate concentrations (difference of +1.1 to $+4.3 \mathrm{mg} / \mathrm{L}$ ). Samples from 4 wells (about 14 percent) indicated moderate to large decreases in nitrate concentrations (difference of -1.1 to $-10 \mathrm{mg} / \mathrm{L}$ ).

A statistical test (paired-t test) was used to mathematically assess whether the average of the 1984 nitrate concentrations was significantly different from the average of the 1996 nitrate concentrations. The test uses the difference between the 1984 and 1996 nitrate concentrations in each of the wells to determine whether there has been an overall change in nitrate concentra- 


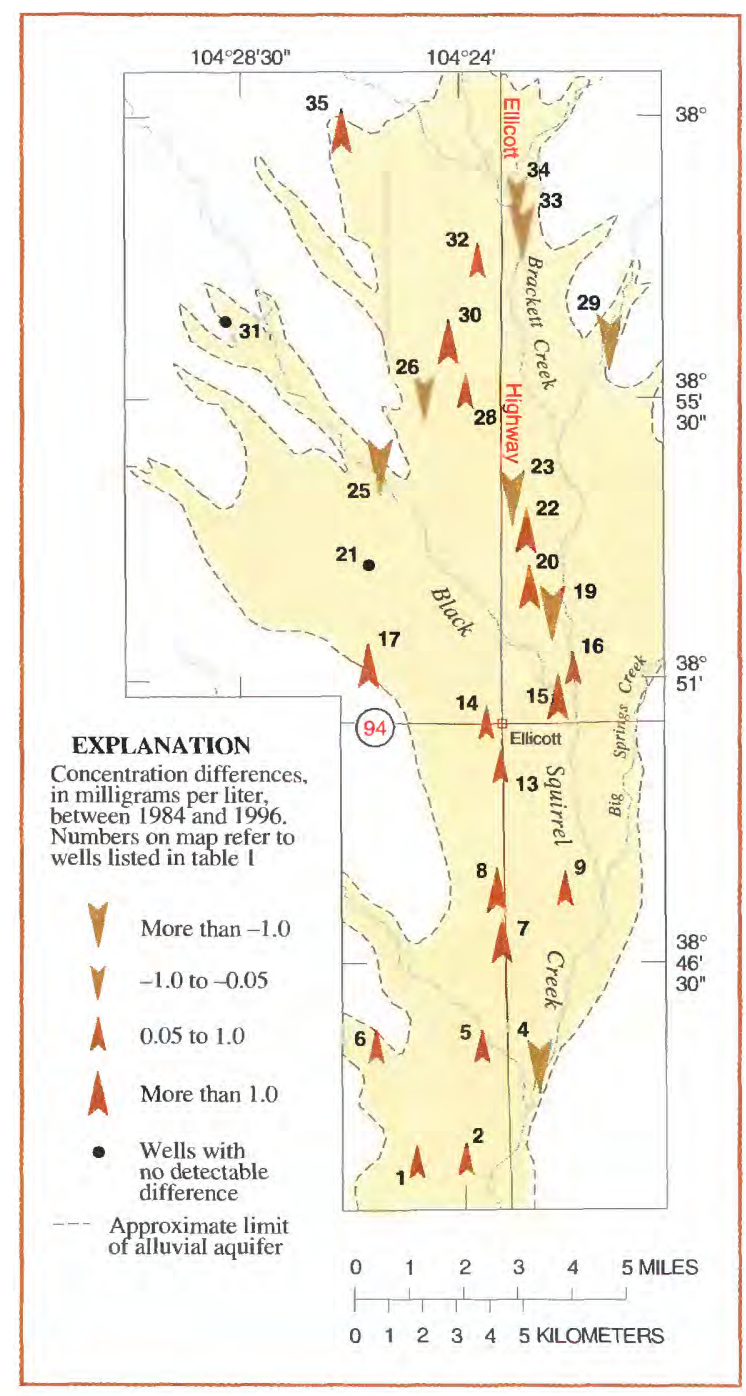

Figure 6. Differences in nitrite plus nitrate as nitrogen (nitrate) concentrations in the alluvial aquifer of upper Black Squirrel Creek between August 1994 and August 1996.

tions in the alluvial aquifer. The statistical analysis of nitrate data from the 28 wells for which there were data for both 1984 and 1996 indicated that there was no significant difference in the average between the 1984 data and the 1996 data $(\mathrm{p}=0.70)$. However, the study area was divided into two subareas, because wells in the southern two-thirds of the basin, south of well 25 , showed a different pattern of change in nitrate concentrations than wells in the northern one-third of the basin, north of well 23 (fig. 6). Additional statistical analysis indicated that nitrate concentrations in the 10 wells sampled in the northern one-third of the basin did not differ significantly between 1984 and 1996 $(p=0.16)$, but nitrate concentrations in the 18 wells sampled in the southern two-thirds of the basin increased significantly between 1984 and $1996(p<0.01)$.

Differences in nitrate concentrations between 1984 and 1996 (fig. 6) may have resulted from:
- changes in the amount of recharge from rainfall and, thus, changes in the amount of nitrate transported from the surface to the aquifer,

$\Rightarrow$ changes in agricultural practices that are a source of nitrate, for example, a change in the amount of animal manure or commercial fertilizers applied to fields,

- changes in the volume of sewage or septic leachfield effluent available for transport to the alluvial aquifer.

Although two samples from each of the 28 wells are not sufficient to definitively determine trends in nitrate concentrations, increases in nitrate concentrations in the alluvial aquifer might be expected in areas where nutrient and water-management practices result in residual nitrate in the soil and nitrate in the unsaturated zone being leached to the water table.

\section{References}

Buckles, D.R., and Watts, K.R., 1988, Geohydrology, water quality, and preliminary simulations of ground-water flow of the alluvial aquifer in the upper Black Squirrel Creek Basin, El Paso County, Colorado: U.S. Geological Survey WaterResources Investigations Report 88-4017, 49 p.

Terblanche, A.P.S., 1991, Health hazards of nitrate in drinking water: Water SA [South Africa], v. 17, no. 1, p. 77-82.

Watts, K.R., 1995, Hydrogeology and simulation of flow between the alluvial and bedrock aquifers in the upper Black Squirrel Creek Basin, El Paso County, Colorado: U.S. Geological Survey Water-Resources Investigations Report 94-4238, $82 \mathrm{p}$.

- The author thanks the well owners who allowed samples to be obtained from their wells and Mark Cuchiara, from the Cherokee Metropolitan District, for his assistance in sampling CMD wells.

- This study was done in cooperation with the Cherokee Metropolitan District.

Information about this study can be obtained from:

Subdistrict Chief

U.S. Geological Survey

Water Resources Division

201 West 8th St., Suite 200

Pueblo, CO 81003-3031

(719) 544-7155, ext. 130

FAX: (719) 544-7155

e-mail: dcain@cronos.usgs.gov
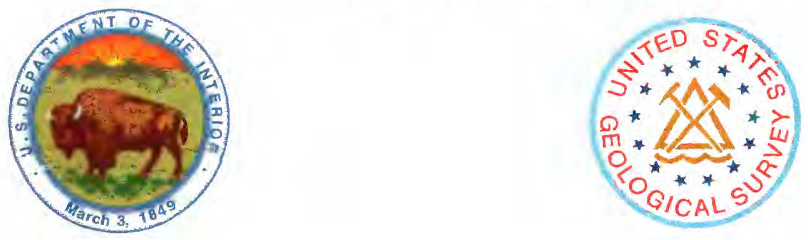